\title{
Pengaruh Profitabilitas Dan Pertumbuhan Perusahaan Terhadap Struktur Modal Pada Perusahaan Manufaktur Dengan Tingkat Inflasi Sebagai Variabel Moderasi
}

\author{
Juvenlianto dan Nyoman Suprastha \\ Program Studi Manajemen, Fakultas Ekonomi dan Bisnis \\ Universitas Tarumanagara, Jakarta \\ Email: juvenlianto5@gmail.com
}

\begin{abstract}
This study was conducted to find out how the influence of profitability and firm growth on capital structure, in this study there is also a moderating variable that is the rate of inflation used to moderate the relationship of firm growth to capital structure. The sample of this research is manufacturing companies listed on the Indonesia Stock Exchange (IDX) in 2015-2017. Processing and testing of research data is done using the EVIEWS 9.0 application program. The results of this study indicate that profitability and firm growth have a negative influence on capital structure, and inflation rates strengthen the relationship of firm size to capital structure.
\end{abstract}

Keywords: Profitability, Firm size, Rate of Inflation, Capital Structure

\begin{abstract}
Abstrak: Penelitian ini dilakukan untuk mengetahui pengaruh profitabilitas dan pertumbuhan perusahaan terhadap struktur modal, dalam penelitian ini juga terdapat variabel moderasi bernama tingkat inflasi yang digunakan untuk memoderasi hubungan pertumbuhan perusahaan dengan struktur modal. Sampel penelitian ini adalah perusahaan manufaktur yang terdaftar di Bursa Efek Indonesia (BEI) 2015-2017. Pemrosesan dan pengujian data penelitian dilakukan dengan menggunakan program aplikasi EVIEWS 9.0. Hasil penelitian ini menunjukkan bahwa profitabilitas dan pertumbuhan perusahaan memiliki pengaruh negatif terhadap struktur modal, dan tingkat inflasi memperkuat hubungan pertumbuhan perusahaan dengan struktur modal.
\end{abstract}

Kata Kunci: Profitabilitas, Pertumbuhan Perusahaan, Tingkat Inflasi, Struktur Modal.

\section{LATAR BELAKANG}

Semakin majunya kondisi perekonomian global saat ini menimbulkan persaingan usaha yang semakin ketat, terlebih saat ini Indonesia sudah memasuki era Asean Economic Community (AEC) atau biasa disebut Masyarakat Ekonomi Asean (MEA). Pembentukan pasar tunggal Masyarakat Ekonomi Asean (MEA) ini memungkinkan satu negara menjual barang dan jasa dengan mudah ke negara - negara lain seluruh Asia Tenggara sehingga kompetisi akan semakin ketat (www.bbc.com). Perusahaan sebagai suatu entitas yang beroperasi dengan menerapkan prinsip- prinsip ekonomi, umumnya perusahaan tidak hanya berorientasi pada pencapaian laba maksimal, tetapi perusahaan juga berusaha meningkatkan nilai perusahaan dan kekayaan pemiliknya, untuk itu perusahaan memiliki rencana strategis dan taktis yang disusun agar dapat mencapai tujuan yang telah ditetapkan (Vitriasari dan Indarti, 2010). Kegiatan operasional perusahaan akan berjalan dengan baik jika manajer 
keuangan perusahaan tepat dalam pengambilan keputusan pendanaan perusahaan. Keputusan pendanaan yang baik tersebut terlihat dari struktur modal perusahaan. Struktur modal merupakan keputusan keuangan yang berkaitan dengan modal, hutang jangka panjang, saham preferen maupun saham biasa yang digunakan oleh perusahaan (Margaretha dan Ramadhan, 2010). Keputusan yang diambil oleh seorang manajer akan berpengaruh pada keberlangsungan perusahaan, oleh karena itu manajer dan perusahaan harus dapat memperhatikan factor- factor yang mempengaruhi struktur modal perusahaan. Faktor tersebut dapat berasal dari keadaan internal perusahaan maupun keadaan eksternal perusahaan.

\section{KAJIAN TEORI}

Menurut Pecking Order Theory yang diungkapkan oleh (Myers dan Maljuf, 1984), teori ini bertujuan menjelaskan bahwa perusahaan dengan keuntungan yang lebih tinggi maka akan cenderung memiliki pinjaman yang lebih kecil karena pembiayaan berasal dari laba ditahan perusahaan tersebut.

Mars (1982) menyatakan bahwa rasio hutang yang optimal ditentukan berdasarkan dengan pengimbangan antara manfaat dan biaya yang timbul akibat penggunaan hutang. Trade-off Theory adalah salah satu teori struktur modal yang menyatakan bahwa perusahaan menukar manfaat pajak dari pendanaan utang dengan masalah yang ditimbulkan oleh potensi kebangkrutan. Teori ini menyarankan untuk menyeimbangkan antara manfaat penggunaan utang dengan risiko penggunaan utang.

Struktur modal terdiri dari sumber pendanaan internal dan sumber pendanaan ekstenal. Dengan membuat struktur modal yang efektif maka akan meningkatkan nilai perusahaan dan membuat investor ingin menanam modal pada perusahaan. Struktur modal adalah perimbangan atau perbandingan antara modal eksternal (jangka panjang) dengan modal internal (Riyanto, 2011). Menurut (Weston dan Copeland, 1999) struktur modal merupakan suatu pembiayaan permanen yang dipilih perusahaan yang terdiri dari hutang jangka panjang, saham preferen, dan modal sendiri.

Profitabilitas merupakan salah satu faktor penting yang akan diperhatikan oleh pemilik perusahaan dan juga para investor. Profitabilitas adalah kemampuan suatu perusahaan untuk mendapatkan laba dalam periode waktu tertentu.Perusahaan dengan tingkat pengembalian investasi yang tinggi memungkinkan perusahaan untuk membiayai kebutuhan pendanaannya dengan menggunakan dana internal (Brigham dan Houston, 2001:40). Dengan perusahaan memperoleh tingkat profitabilitas yang tinggi maka kecil kemungkinan perusahaan untuk membutuhkan pendanaan dari luar perusahaan.

Menurut Brigham dan Houston (2001) pertumbuhan perusahaan adalah perubahan aset setahun dilihat dari total aktivanya. Setiap perusahaan pasti menginginkan pertumbuhan yang tinggi setiap tahunnya. Dengan bertumbuhnya perusahaan maka keuntungan akan meningkat, sehingga pendanaan internal perusahaan meningkat, untuk membuat pertumbuhan ini tercapai, perusahaan membutuhkan dana yang cukup besar. Dana yang digunakan akan mempengaruhi struktur modal, manajemen akan mempertimbangkan bantuan pendanaan dari internal atau ekstenal.

Inflasi merupakan salah satu faktor masalah dalam ekonomi suatu negara. Jika kenaikan harga yang terjadi hanya sekali saja dan bersifat sementara atau secara temporer (sekalipun dalam presentase yang besar) tetapi tidak berdampak meluas maka bukan dikatakan inflasi (Prasetyo, 2011:195). Dengan adanya kenaikan harga tersebut, maka 
perusahaan akan lebih memilih untuk menggunakan utang karena akan mengurangi pengeluaran modal yang terlalu banyak dari pendanaan secara internal. Model penelitian dalam penelitian ini seperti digambarkan dibawah ini :

\section{Gambar 1 Model Penelitian}

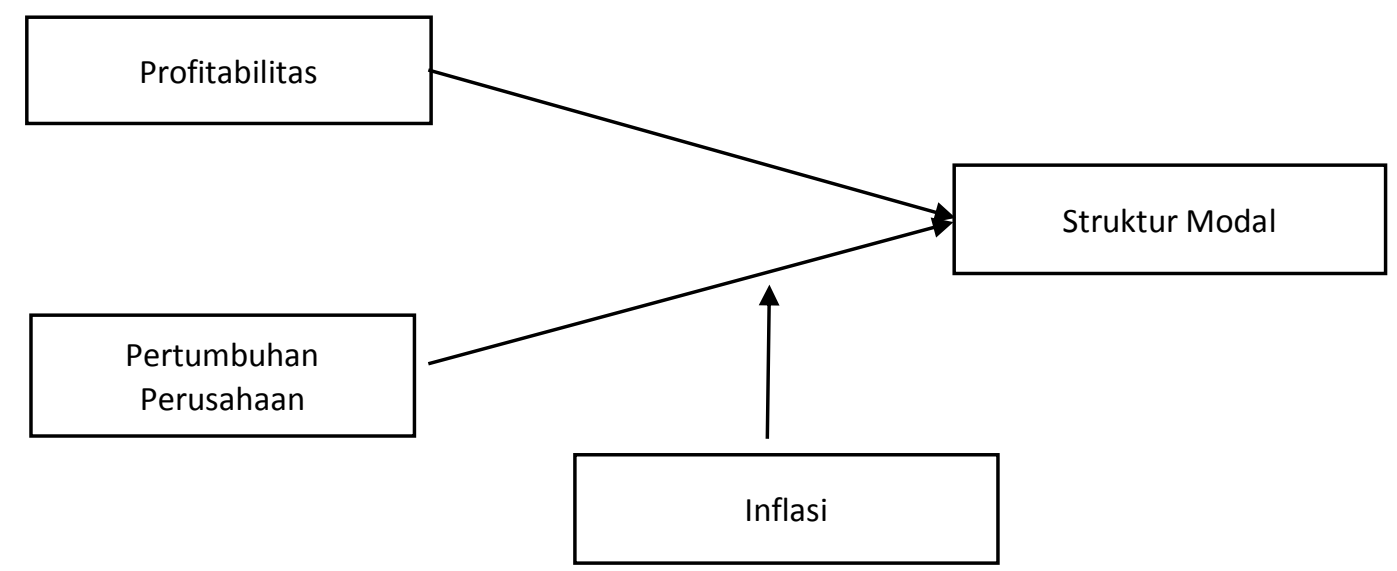

Hipotesis dari model penelitian diatas adalah sebagai berikut :

H1 : $\quad$ Profitabilitas memiliki pengaruh negative terhadap struktur modal perusahaan. $\mathrm{H}$ 2: $\quad$ Pertumbuhan perusahaan memiliki pengaruh positif tehadap struktur modal perusahaan.

H3: $\quad$ Tingkat inflasi akan memperkuat hubungan pengaruh pertumbuhan perusahaan terhadap struktur modal.

\section{METODOLOGI}

Subyek yang dipilih dalam penelitian ini adalah perusahaan manufaktur yang terdaftar di Bursa Efek Indonesia periode 2015-2017. Metode yang dipakai untuk penelitian ini adalah dengan menggunakan teknik non-probability sampling yaitu purposive sampling. Objek yang diperoleh dalam penelitian ini yaitu jumlah sampel sebanyak 115 perusahaan yang memenuhi syarat. Variabel operasional dalam penelitian ini terdiri dari profitabilitas, dan pertumbuhan perusahaan yang merupakan variabel independen dan struktur modal sebagai variabel dependen. Peneliti juga menggunakan variabel moderasi yaitu inflasi.

Dalam penelitian ini struktur modal diwakili oleh Debt to Asset Ratio (DAR) dengan rumus

Debt to Asset Ratio $($ DAR $)=\frac{\text { Total Debt }}{\text { Total Aset }}$

Profitabilitas dalam penelitian ini profitabilitas diwakili dengan Return on Asset (ROA) dengan rumus :

Return On Asset $($ ROA $)=\frac{\text { Earning After Tax }}{\text { Total Asset }}$ 
Sedangkan pertumbuhan perusahaan dalam penelitian diwakili dengan Asset Growth dengan rumus:

Asset Growth $=\frac{\text { Total Asset }_{t}-\text { Total Asset }_{t-1}}{\text { Total Asset }_{t-1}}$

Dalam penelitian ini, peneliti menggunakan uji Analisis Statistik Deskriptif untuk menguji data sampel, kemudian Uji Likelihood dan Uji Hausman untuk menentukan pemilihan fixed effect model, common model effect, atau random effect model dan terakhir Uji Analisis Regresi Berganda

\section{HASIL ANALISIS DATA}

Dalam pengujian Analisis Statistik Deskriptif diperhitungkan Mean (Rata-rata), Median (Nilai Tengah), Maximum (Nilai tertinggi), Minimum (Nilai terendah), Standar Deviasi. Hasil Analisis Statistik Deskriptif Struktur Modal memiliki nilai rata- rata sebesar 0.495728 , nilai tengah atau median dari struktur modal adalah sebesar 0.487546 , nilai tertinggi dari struktur modal adalah 2.073112, nilai terendah dari struktur modal adalah 0.000300 , dan nilai standar deviasi struktur modal adalah sebesar 0.279131. Nilai profitabilitas rata- rata (mean) adalah sebesar 0.046473, nilai tengah (median) dari profitabilitas adalah sebesar 0.034534 , nilai tertinggi profitabilitas adalah sebesar 0.567540 , nilai minimum dari profitabilitas adalah sebesar -0.548470 , dan nilai standar deviasi probabilitas adalah sebesar 0.105164 . Nilai pertumbuhan perusahaan rata- rata (mean) adalah sebesar 0.100069 , nilai tengah (median) dari pertumbuhan perusahaan adalah sebesar 0.052297 , nilai tertinggi pertumbuhan perusahaan adalah sebesar 9.313719, nilai terendah dari pertumbuhan perusahaan adalah sebesar -0.999906, dan nilai standar deviasi dari pertumbuhan perusahaan adalah sebesar 0.541655 .

Uji likelihood digunakan untuk memilih antara model mana yang akan digunakan dalam pengujian regresi, terdapat dua pilihan model dalam uji ini yaitu common model atau fixed effect model. Tingkat keyakikan yang digunakan dalam penelitian ini adalah sebesar 95\%, sehingga memiliki nilai signifikansi sebesar 5\%. Berikut hasil uji dapat dilihat dari tabel dibawah ini.

Tabel 1

Hasil Uji Likelihood

Redundant Fixed Effects Tests

Equation: Untitled

Test cross-section fixed effects

\begin{tabular}{lrrr}
\hline \hline Effects Test & Statistic & d.f. & Prob. \\
\hline \hline Cross-section F & 6.224974 & $(114,228)$ & 0.0000 \\
Cross-section Chi-square & 487.839640 & 114 & 0.0000 \\
\hline \hline
\end{tabular}


Hasil pengujian menunjukkan nilai dari probabilitas cross-section $\mathrm{F}$ adalah sebesar 0,0000. Hasil tersebut lebih kecil dari nilai signifikan 0,05. Dari hasil uji tersebut maka Ho ditolak dan Ha diterima, sehingga Fixed Effect Model lebih tepat digunakan untuk melakukan analisis regresi.

Uji hausman digunakan untuk menentukan model mana yang akan digunakan dalam pengujian regresi, terdapat dua pilihan model dalam uji ini yaitu Fixed Effect Model atau Random Effect Model. Tingkat keyakinan yang digunakan dalam penelitian ini adalah sebesar 95\% sehingga memiliki nilai signifikansi sebesar 5\%. Berikut hasil uji dapat dilihat dari tabel dibawah ini.

Tabel 2

Hasil Uji Hausman

Correlated Random Effects - Hausman Test

Equation: Untitled

Test cross-section random effects

\begin{tabular}{lrrr}
\hline \hline Test Summary & $\begin{array}{c}\text { Chi-Sq. } \\
\text { Statistic }\end{array}$ & Chi-Sq. d.f. & Prob. \\
\hline \hline Cross-section random & 6.065668 & 2 & 0.0482 \\
\hline \hline
\end{tabular}

Hasil pengujian menunjukkan nilai dari probabilitas cross-section random adalah sebesar 0.0482, hasil tersebut lebih kecil dari nilai signifikan 0,05. Dari hasil uji tersebut maka Ho ditolak dan Ha diterima, sehingga Fixed Effect Model lebih tepat digunakan untuk melakukan analisis regresi.

Berdasarkan hasil dari kedua uji tersebut yaitu uji likelihood dan uji hausman, maka dapat disimpulkan model yang akan digunakan untuk pengujian analisis regresi adalah Fixed Effect Model.

Pada pengujian Analisis regresi berganda digunakan persamaan yang menggunakan variabel moderasi sehingga berikut adalah hasil yang diperoleh. Hasil pengujian profitabilitas memiliki nilai konstanta sebesar 0.524466, jika nilai profitabilitas dan error dianggap nol (0), maka nilai struktur modal adalah sebesar 0.524466. Nilai koefisien regresi profitabilitas adalah sebesar -0.395254 , sehingga dapat dikatakan bahwa profitabilitas memberikan pengaruh negative terhadap struktur modal. Jika nilai profitabilitas naik satu (1) satuan dengan nilai error adalah nol (0), maka struktur modal akan mengalami penurunan sebesar 0.395254. Dari hasil model regresi yang telah dibuat, hasil pengujian analisis regresi menunjukan nilai probabilitas variabel profitabilitas adalah sebesar 0.0451, nilai profitabilitas dari profitabilitas lebih kecil dari 0.05. Maka dapat disimpulkan bahwa hipotesis awal diterima karena profitabilitas memberikan pengaruh negative terhadap struktur modal.

Hasil pengujian pada pertumbuhan perusahaan memiliki nilai konstanta sebesar 0.524466, jika nilai pertumbuhan perusahaan dan error dianggap nol (0), maka nilai struktur modal adalah sebesar 0.524466. Nilai koefisien regresi pertumbuhan perusahaan adalah sebesar -0.103624, sehingga dapat dikatakan bahwa pertumbuhan perusahaan memberikan pengaruh negative terhadap struktur modal. Jika nilai pertumbuhan perusahaan naik satu (1) 
satuan dengan nilai error adalah nol (0), maka struktur modal akan mengalami penurunan sebesar 0.103624. Dari hasil model regresi yang telah dibuat, hasil pengujian analisis regresi menunjukan nilai probabilitas variabel pertumbuhan perusahaan adalah sebesar 0.0000 , nilai profitabilitas dari pertumbuhan perusahaan lebih beasr dari 0.05. Maka dapat disimpulkan bahwa hipotesis awal ditolak karena pertumbuhan perusahaan memberikan pengaruh negative terhadap struktur modal perusahaan manufaktur yang terdaftar di Bursa Efek Indonesia tahun 2015-2017.

Hasil pengujian pada inflasi sebagai variabel moderasi pada hubungan antara pertumbuhan perusahaan dan struktur modal memiliki nilai konstanta sebesar 0.525299 , jika nilai pertumbuhan perusahaan dan error dianggap nol (0), maka nilai struktur modal adalah sebesar 0.525299. Nilai koefisien regresi pertumbuhan perusahaan adalah sebesar 0.179612, sehingga dapat dikatakan bahwa pertumbuhan perusahaan memberikan pengaruh positif terhadap struktur modal. Jika nilai pertumbuhan perusahaan naik satu (1) satuan dengan nilai error adalah nol (0), maka struktur modal akan mengalami kenaikan sebesar 0.179612. Dari hasil model regresi yang telah dibuat, hasil pengujian analisis regresi menunjukan nilai probabilitas variabel pertumbuhan perusahaan adalah sebesar 0.6371, nilai probabilitas dari pertumbuhan perusahaan lebih beasr dari 0.05. Berdasarkan hasil dari uji analisis regresi tersebut maka dapat disimpulkan pertumbuhan perusahaan memberikan pengaruh positif terhadap struktur modal.

\section{DISKUSI}

Hasil pengujian yang dilakukan menunjukkan bahwa Profitabilitas berpengaruh negatif dan signifikan terhadap Struktur modal perusahaan. Hasil pengujian ini menunjukkan bahwa Pertumbuhan perusahan berpengaruh negatif dan tidak signifikan terhadap Struktur modal perusahaan. Hasil pengujian ini menunjukkan bahwa variabel moderasi yaitu inflasi memperkuat hubungan antara Pertumbuhan perusahaan dengan Struktur modal perusahaan.

\section{PENUTUP}

(1) Berdasarkan hasil pengujian data dalam penelitian ini menunjukan bahwa Struktur modal dipengaruhi oleh Profitabilitas, Pertumbuhan Perusahaan, dan inflasi pada perusahaan manufaktur yang terdaftar di Bursa Efek Indonesia periode 2013-2017. (2) Dalam melakukan penelitian ini juga terdapat keterbatasan- keterbatasan antara lain adalah variabel independent yang digunakan untuk pengujian. Hanya terdapat 2 variabel independent yang digunakan dalam penelitian ini yaitu profitabilitas, dan pertumbuhan perusahaan. Selain itu juga terdapat variabel moderasi dalam penelitian ini yaitu tingkat inflasi, tetapi dalam penelitian ini tingkat inflasi hanya digunakan untuk memoderasi hubungan pengaruh pertumbuhan perusahaan terhadap struktur modal. Penelitian ini juga terbatas pada jumlah sampel yang digunakan, yaitu perusahaan manufaktur yang terdaftar di Bursa Efek Indonesia tahun 2015-2017. (3) Bersadarkan hasil dan keterbatasan diatas maka saran yang dapat diberikan untuk penelitian selanjutnya adalah menambah jumlah variabel dan variabel moderasi yang akan digunakan untuk mengetahui pengaruh terhadap struktur modal, sehingga hasil penelitian dapat lebih akurat, dan memperpanjang periode penelitian, dalam penelitian ini memiliki periode selama 3 tahun dari tahun 2015-2017, diharapkan penelitian selanjutnya menggunakan periode yang lebih panjang dari 3 tahun. 


\section{DAFTAR PUSTAKA}

Ali, Irfan. 2011. "Determinants of Capital Structure: Empirical Evidence from Pakistan."

Ashari, Darsono dan. 2005. Pedoman Praktis Memahami Laporan Keuangan. Yogyakarta: Penerbit ANDI.

Boediono. 1999. Teori Pertumbuhan Ekonomi. Yogyakarta: BPFE.

Brealey, Richard A., and Stewart C. Myers. 2002. Corporate Finance: Capital Investment and Valuation. United States: McGraw-Hill; 1 edition.

Brigham, and Houston. 2001. Manajemen Keuangan. Jakarta: Penerbit Erlangga.

Kashmir. 2010. Analisis Laporan Keuangan. Jakarta: Rajawali Pers.

Lumbantobing, Rudolf, and Leonardus Saiman. 2012. "INFLASI SEBAGAI VARIABEL MAKRO EKONOMI PEMODERASI DETERMINAN STRUKTUR MODAL PERUSAHAAN SEKTOR INDUSTRI MANUFAKTUR YANG GO PUBLIC DI BURSA EFEK INDONESIA."

Myers, Stewart C., and Nicholas S. Majluf. 1984. "Corporate financing and investment decisions when firms have information that investors do not have." Journal of financial economics 13(2), 187-221.

Riyanto, Bambang. 2011. Dasar- Dasar Pembelanjaan Perusahaan. Yogyakarta: Penerbit BPFE.

Saurabh, Chadha, and Anil K. Sharma. Vol. 12 No. 1, 2015. "Determinants of capital structure: an empirical evaluation from India." Journal of Advances in Management Research 3-14.

Sutrisno. 2013. Manajemen Keuangan; Teori Konsep dan Aplikasi, Cetakan ke-9. Yogyakarta: Ekonisis.

T., Mayuri, and Lingesia Kengatharan. 2019. "Determinants of Capital Structure: Evidence from Listed Manufacturing Companies in Sri Lanka." SCMS Journal of Indian Management.

Teng, Adelyne, and Jonnardi. 2019. "Analisis Faktor - Faktor Yang Mempengaruhi Struktur Modal Dengan Inflasi Sebagai Variabel Moderasi." Jurnal Multiparadigma Akuntansi 145-152 .

Wachowicz, JC Van Horne \& JM. 2008. Fundamentals of Financial Management. Pearson Education Limited.

https://www.bbc.com/indonesia/berita_indonesia/2014/08/140826_pasar_tenaga_kerja_ae $c$. 